\title{
Environmental Effect of Mining Granite in Sauna Community of
}

\section{Kano State}

\author{
Kurumeh Johnleonard Chigozie \\ UNN/SHELL Center for Environmental Management and Control, University of Nigeria, Nsukka, Nigeria. \\ E-mail of the corresponding author: johnleonard.kurumeh@unn.edu.ng
}

\begin{abstract}
Artisanal solid mineral mining in Sauna Community of Kano State has resulted to environmental consequence.This is due to heavy metal pollution. A study of the environmental effect of Granite mining in Sauna Community of Kano state was carried out. Heavy metals such as $\mathrm{Fe}, \mathrm{Pb}, \mathrm{Cu}, \mathrm{Cr}, \mathrm{Ni}, \mathrm{Zn}$ and $\mathrm{Cd}$ were determined using Atomic absorption spectrometry. The water quality of the surface water and mine pit water was evaluated using WQI. The surface water was polluted by cadmium, lead, nickel and chromium as the mean concentration of these four heavy metals occurred at higher concentration than the prescribed levels of WHO and SON. Consequently, the water quality ranking is very poor at WQI value of 213 . The mine pit water is also of poor quality having been polluted by cadmium, lead and nickel yielding WQI of 178. Water quality index was employed in the assessment of the water quality of the impacted water bodies so as to ascertain how the quality of such water bodies has been affected by the mining activities. This study assessed pollution of the soils and sediments by heavy metals arising from mining activities using contamination factor, degree of contamination, geochemical accumulation index, pollution load index and potential ecological risk index. The contamination factor (CF) for all the heavy metals in the sediments of the surface water were below the background levels hence indicating there was no contamination of these heavy metals in the sediments. Given the degree of contamination of 0.9 for the sediment which is less than 8.0, the degree of contamination of the sediment is classified as insignificant. The pollution load index (PLI) is less than unity indicating no pollution. The geoaccumulation index (Igeo) is less than zero for each of the heavy metals indicating non-pollution. The potential ecological risk index of the heavy metals in the sediment is evaluated as 2.4 which is far less than 40 indicating low/insignificant ecological risks.
\end{abstract}

Keywords: Solid Mineral, Mining, Heavy Metals, Water quality, Pollution.

DOI: $10.7176 / \mathrm{JEES} / 11-5-09$

Publication date:May $31^{\text {st }} 2021$

\section{INTRODUCTION}

It is a fact that Nigeria is endowed with several solid mineral resources namely, galena, iron ore, feldspar, kaolin, limestone, gold, tin ore etc. Available data shows that the prospects lie in the diverse solid minerals of 33 different types occurring in large quantities in 450 locations within the geological formation; pre-Cambrian igneous and metamorphic rocks of the basement complex and sedimentary rocks but which are in poor stages of exploitation for export. (Odeyemi 2001 and Olufemi et al.,2014 ).As E.C. Merem (2017) observed, the market worth of Nigeria's Solid minerals stands at hundreds of trillions of Dollars throughout the country. Regrettably, there is no sufficient data to measure the viability of the huge solid mineral deposits across the nation. Huge investment in solid mineral sector of the economy could be a viable alternative source of revenue for the country if well developed and could place Nigeria among the top economies of the world. However, the sustainable development of the solid mineral sector in Nigeria requires sufficient knowledge of how the activities of solid mineral mining interact with the environment in light of the prevailing technology available to both the artisanal and large scale miners. It is obvious that any development that does not take place in tandem with environmental stewardship that guarantees healthy environment for all generations cannot be said to be sustainable.

Studies have revealed that large quantities of pollutants have continuously been introduced into ecosystems as a consequence of urbanization and industrial processes. (Begun et al; (2009) and Adelekan et al 2011).These pollutants are persistent in nature and which can biomagnify to hurt humans and the environment. The pollutants are the heavy metals, examples include $\mathrm{Cu}, \mathrm{Cr}, \mathrm{Cd}, \mathrm{Ni}$, and $\mathrm{Pb}$. They are elements with density greater than $4 \mathrm{~g} / \mathrm{cm}^{3}$. Naturally, they are found in rocks and soils but pollution often alter the concentration. ( Tsafe et al; (2012). Through artisanal or large scale mining, by-products of mining process find their way into the 
environment. The presence of harmful heavy metals in the environment, particularly above their threshold levels, leads to environmental pollution and ultimately causes serious health problems for humans and animals. (Ebenebe PC, Shale K, Sedibe M, et al; 2017).

Soil, as a critical component of the environment, takes up the pollutants produced due to large or small scale mining activities. Different processes interact together to aid the movements of heavy metals in soil. These polluted soils serve as the source of dispersal of heavy metals in the environment and may enter the food chain and food web.( Yahaya, S.M et al;(2021). The biggest problems of the heavy metals are persistent and nondegradable, their presence in soil is stable and long-term, and these pose risks to public health and the environment.( Wu Y, et al; (2015) and Yahaya, S.M (2021). It is against this backdrop that this study is carried out to establish the environmental status quo as attributable to mining activities. The study therefore is meant to ascertain the possible extent of pollution of the immediate environment of the granite mining activities in Sauna Community in Kano State.

\section{METHODOLOGY}

\subsection{Study Area}

The study area was Sauna Community in Kano State where the mining site for artisanal granite mining is situated. The georeference of the study site and map of the study area are presented in Table 1 and Figure 1

Table 1 Geo-reference of samples collected at granite mine site in Sauna Community, Kano State

\begin{tabular}{|c|c|c|}
\hline $\mathrm{S} / \mathrm{N}$ & Georeference & \\
\hline & Soil samples & \\
\hline 1 & Lat. N12 1 '41.38" & Long. E8³6 $3.38^{\prime \prime}$ \\
\hline 2 & Lat. N12॰1 ' $42.57^{\prime \prime}$ & Long. E8³6 ' 2.87 " \\
\hline 3 & Lat. N12॰1 ' $41.11^{\prime \prime}$ & Long. E8 $36^{\prime} 3.17^{\prime \prime}$ \\
\hline 4 & Lat. $\mathrm{N} 12^{\circ} 0$ ' $52.3^{\prime \prime}$ & Long. E8³6 '23.9" \\
\hline 5 & Lat. $\mathrm{N} 12^{\circ} 0^{\prime} 51.7^{\prime \prime}$ & Long. E8³6' 23.0" \\
\hline Surf & ples & \\
\hline 1 & Lat. N12 1 ' $33.8^{\prime \prime}$ & Long. E8³6' $25.8^{\prime \prime}$ \\
\hline 2 & Lat. N12॰1 $33.75^{\prime \prime}$ & Long. E8³6' 25.6" \\
\hline 3 & Lat. N12॰1'34.26" & Long. E8³6' 25.9" \\
\hline 4 & Lat. N12 $0^{\circ} 57.4^{\prime \prime}$ & Long. E8³6' $3.37^{\prime \prime}$ \\
\hline 5 & Lat. N12॰1 $0.35^{\prime \prime}$ & Long. E8 ${ }^{\circ} 36^{\prime} 4.47^{\prime \prime}$ \\
\hline 6 & Lat. N12 ${ }^{\circ} 1$ ' $1.272^{\prime \prime}$ & Long. E8 ${ }^{\circ} 36^{\prime} 5.01^{\prime \prime}$ \\
\hline Sedi & & \\
\hline 1 & Lat. N12 1 ' $33.8^{\prime \prime}$ & Long. E8³6' $25.8^{\prime \prime}$ \\
\hline 2 & Lat. N12॰1'33.75" & Long. E8³6' 25.6" \\
\hline 3 & Lat. N12॰1'34.26" & Long. E8 ${ }^{\circ} 36^{\prime} 25.9^{\prime \prime}$ \\
\hline 4 & Lat. N12 0 ' $40.64 "$ & Long. E8 $35^{\prime} 53.08^{\prime \prime}$ \\
\hline 5 & Lat. $\mathrm{N} 12^{\circ} 0{ }^{\prime} 40.5^{\prime \prime}$ & Long. E8 $35^{\prime} 53.2^{\prime \prime}$ \\
\hline 6 & Lat. $\mathrm{N} 12^{\circ} 0{ }^{\prime} 40.06^{\prime \prime}$ & Long. E8³5' $53.1^{\prime \prime}$ \\
\hline
\end{tabular}




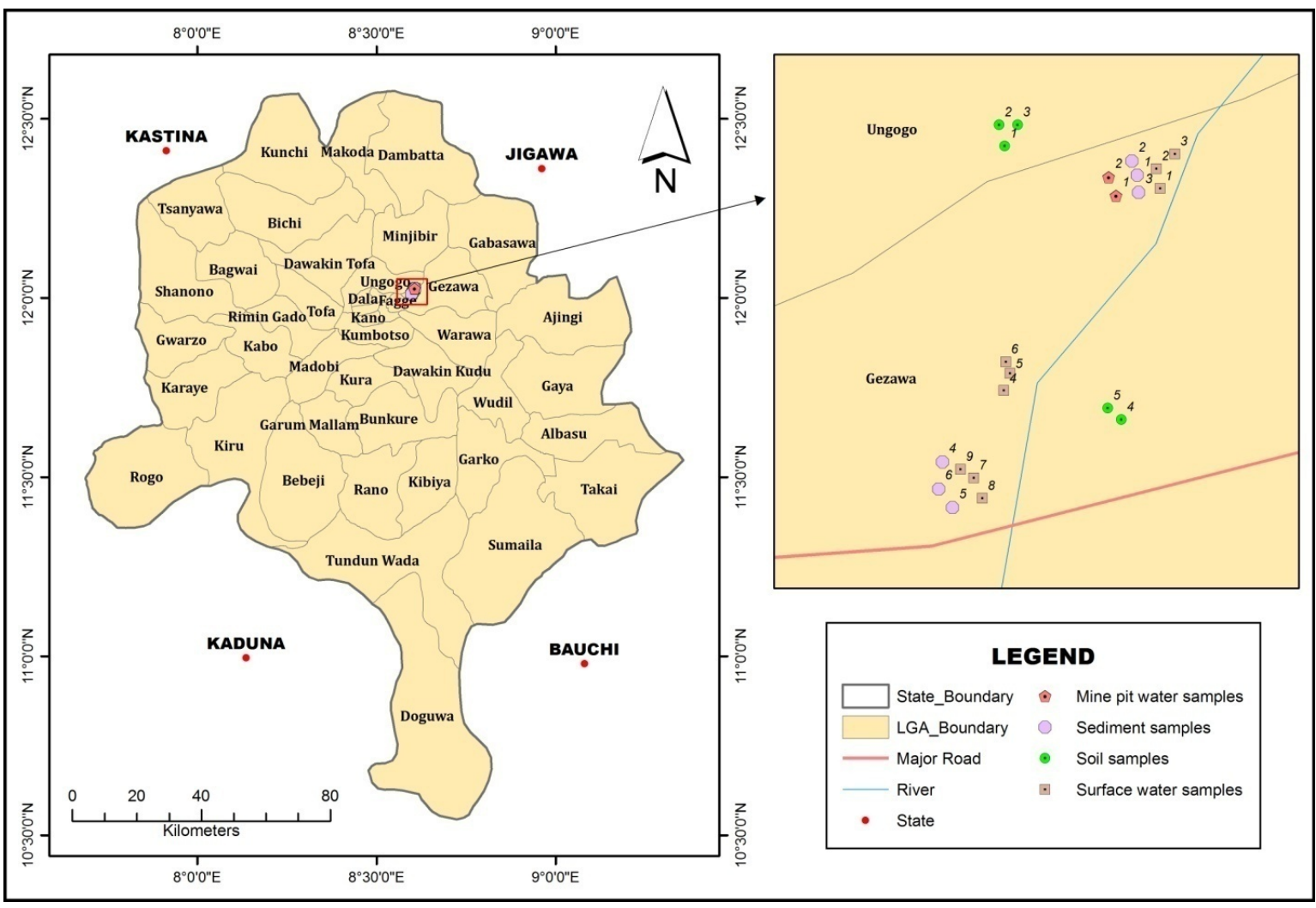

Figure 1 Map of the study area showing surface water, soil and sediment sampling points for the granite site located in Sauna Community, Kano State.

\subsection{Sampling}

Sample collection for the study took place between $5^{\text {th }}$ of July 2019 and $22^{\text {nd }}$ of August 2019. Water samples were collected using 1 litre polyethylene cans.

\subsection{Water Sample Analysis}

The surface water samples collected were transferred to two separate sterilized $1 \mathrm{~L}$ sample bottles for physicochemical and heavy metal analysis. For the heavy metals, it was ensured that the $1 \mathrm{~L}$ sample bottles were previously cleaned with nitric acid $\left(\mathrm{HNO}_{3}\right)$. The collected water samples were then acidified by means of $5 \mathrm{~mL}$ of $6 \mathrm{M} \mathrm{HNO}_{3}$ prior to laboratory analysis.

Heavy metals such as $\mathrm{Fe}, \mathrm{Pb}, \mathrm{Cu}, \mathrm{Cr}, \mathrm{Ni}, \mathrm{Zn}$ and $\mathrm{Cd}$ were determined using Atomic absorption spectrometry as prescribed by the standard method of APHA (1998). The physico-chemical parameters namely: $\mathrm{Cl}, \mathrm{SO}_{4}, \mathrm{NO}_{3}$, $\mathrm{pH}$, conductivity, total suspended solids (TSS) and total dissolved solids (TDS) were measured following the standard method of APHA (1998). For the heavy metals, the quality assurance include: determination of limit of detection (LOD), limit of quantification (LOQ) and recoveries. The LOD was determined as three times the standard deviation of 10 replicate blank measurements (Pekey et al., 2004). The LOQ was determined as three times the LOD value. The LOD varied from $0.0002-0.0005 \mathrm{mg} / \mathrm{L}$; LOQ varied from $0.0005-0.0015 \mathrm{mg} / \mathrm{L}$; recoveries varied from $82-93 \%$. 


\subsection{Water Quality Assessment Using Water Quality Index}

Water quality index was employed in the assessment of the water quality of the impacted water bodies so as to ascertain how the quality of such water bodies has been affected by the mining activities. This is extremely important considering the fact that the host communities use the water bodies for purposes of cooking and drinking.

The water quality index of the impacted surface water was evaluated following the procedure by Sahu and Sikdar (2008). Water quality ranking using WQI was based on the following scheme: < 50 implies excellent water; 50-100 implies good water; 100-200 implies poor water; 200-300 implies very poor water; $>300$ implies water unsuitable for drinking (Sahu and Sikdar, 2008).

\subsection{Pollution Assessment and ecological risks due to heavy metals in soil and sediments}

This study assessed pollution of the soils and sediments by heavy metals arising from mining activities using contamination factor, degree of contamination, geochemical accumulation index, pollution load index and potential ecological risk index. Contamination factor (CF) is a very useful tool in identifying the contamination level of soils and sediments by the individual heavy metals. Because the degree of contamination (CD) considers all the measured heavy metals, it is useful in estimating the cumulative level of contamination. The geochemical accumulation index $\left(\mathrm{I}_{\mathrm{geo}}\right)$ provides a measure of the extent of the heavy metal contamination compared to background levels. It therefore provides evidence for anthropogenic releases of the heavy metals in the soils and sediments. Pollution load index (PLI) is a good tool used in estimating the extent of pollution of the soils and sediments. Hence, $\mathrm{CF}, \mathrm{CD}, \mathrm{I}_{\mathrm{geo}}$ and PLI were used in the assessment of pollution of sediments and soils by heavy metals. The potential ecological risk index (PERI) estimates risks posed to biota inhabiting the sediments from the heavy metal pollution of the sediments. PERI was therefore evaluated and employed in assessing potential risks to the biota living in the contaminated sediments and soil.

\subsubsection{Contamination Factor}

Contamination factor (CF) is a very useful tool used in identifying the contamination level of sediments by heavy metals (Hakanson, 1980).

$\mathrm{CF}=\mathrm{C}_{\text {sediment }} / \mathrm{C}_{\text {background }}$--------------------------------------------Eq. 1

Where: $\mathrm{C}_{\text {sediment }}=$ heavy metal mean concentration in the sediment; $\mathrm{C}_{\text {background }}=$ heavy metal concentration in the background

The background values used in this study are those reported by Hakanson (1980).

\subsubsection{Degree of Contamination}

The degree of contamination (DC) is estimated by adding the CF for all the heavy metals in the sample as described in equation 2 .

$\mathrm{DC}=\mathrm{CF}_{1}+\mathrm{CF}_{2}+\mathrm{CF}_{3}+\ldots \ldots \ldots \ldots \ldots \ldots \mathrm{CF}_{\mathrm{n}}$-----------------------Eq. 2 


\subsubsection{Geochemical-accumulation index ( $\left.\mathbf{I}_{\text {geo }}\right)$}

The geo-accumulation index $\left(\mathrm{I}_{\mathrm{geo}}\right)$ is computed as follows:

$I_{\text {geo }}=\log _{2}\left(\mathrm{C}_{\mathrm{n}} / 1.5 \mathrm{~B}_{\mathrm{n}}\right)$--------------------------------------------------Eq. 3

Where: $C_{n}=$ concentration of heavy metals in the sediment; $B_{n}=$ geochemical background value

1.5 is the matrix correction factor for minimizing lithogenic effects (Yi et al., 2016).

\subsubsection{Pollution Load Index (PLI)}

Pollution load index (PLI) is a veritable tool used in measuring the extent of pollution of the sediments and is expressed as (Tomlinson et al., 1980):

$\mathrm{PLI}=\left(\mathrm{CF}_{1} * \mathrm{CF}_{2} * \mathrm{CF}_{3} * \ldots \ldots \ldots \ldots . . . \mathrm{CF}_{\mathrm{n}}\right)^{1 / \mathrm{n}}$-----------------------Eq. 4

Where: $\mathrm{CF}=$ contamination factor; $\mathrm{n}=$ number of heavy metals in the sediment sample

\subsubsection{Potential Ecological Risk Index (PERI)}

The potential ecological risk index PERI of the heavy metals in the sediments was derived from summing the potential ecological risk factor (PERF) of the individual heavy metals.

$\mathrm{PERF}=\mathrm{CF} * \mathrm{TRC}$ -Eq. 5

Where: $\mathrm{CF}=$ contamination factor

TRC $=$ toxic response coefficient for a given heavy metal. This study adopted the TRC reported in Hakanson (1980). TRC is actually an indication of a heavy metal's toxicity and ecological sensitivity, hence the higher the coefficient the more toxic and ecological sensitivity (Guo et al., 2010).

$\mathrm{PERI}=\mathrm{PERF}_{1}+\mathrm{PARF}_{2}+\mathrm{PERF}_{3}+\ldots \ldots \ldots . . \mathrm{PERF}_{\mathrm{n}}$---------------Eq. 6

\subsection{Physico-chemistry Parameters and concentration of the heavy metals}

The values of the physico-chemistry parameters and concentration of the heavy metals in the surface water of the surrounding environment are as presented in Tables 2 and 3. 
Table 2 Values of the physico-chemical parameters of the stream (surface water) around the granite site at Sauna Community, Kano State (See geo-ref in Table 65). DW1-DW6 and DW7-DW9 were test and control sampling points

\begin{tabular}{|c|c|c|c|c|c|c|c|c|c|c|c|c|c|c|c|}
\hline \multirow[t]{2}{*}{$\begin{array}{l}\text { Samp } \\
\text { le }\end{array}$} & $\mathrm{pH}$ & $\begin{array}{l}\mathrm{Cl} \\
(\mathrm{mg} \\
/ \mathrm{L})\end{array}$ & $\begin{array}{l}\mathrm{EC} \\
\mu \mathrm{S} / \\
\mathrm{cm}\end{array}$ & $\begin{array}{l}\text { TDS } \\
(\mathrm{mg} / \\
\mathrm{L})\end{array}$ & $\begin{array}{l}\text { (mg/ } \\
\text { L) }\end{array}$ & $\begin{array}{l}\text { BOD } \\
(\mathrm{mg} / \\
\mathrm{L})\end{array}$ & $\begin{array}{l}(\mathrm{mg} / \\
\mathrm{L})\end{array}$ & $\begin{array}{l}(\mathrm{mg} / \\
\mathrm{L})\end{array}$ & $\begin{array}{l}(\mathrm{mg} / \\
\mathrm{L})\end{array}$ & $\begin{array}{l}\text { TO } \\
\text { C }\end{array}$ & $\begin{array}{l}\text { (mg } \\
\mathrm{Ll})\end{array}$ & $\begin{array}{l}\mathrm{NH} 4 \\
-\mathrm{N} \\
(\mathrm{mg} / \\
\mathrm{L})\end{array}$ & $\begin{array}{l}(\mathrm{mg} / \\
\mathrm{L})\end{array}$ & $\begin{array}{l}\text { (mg/ } \\
\text { Ll) }\end{array}$ & $\begin{array}{l}\mathrm{SO}_{4} \\
(\mathrm{mg} / \\
\mathrm{L})\end{array}$ \\
\hline & \multicolumn{15}{|c|}{ Surface water } \\
\hline DW1 & 6.83 & 80.00 & 220 & 109.7 & 6.5 & 0.76 & 4.32 & 6.80 & 13.70 & 0.05 & 0.38 & 0.009 & 1.01 & 0.033 & 74.96 \\
\hline DW2 & 6.86 & 80.00 & 220 & 109.7 & 6.0 & 0.70 & 4.32 & 6.80 & 13.70 & 0.05 & 0.35 & 0.010 & 1.11 & 0.036 & 74.96 \\
\hline DW3 & 6.88 & 81.45 & 224 & 111.7 & 6.7 & 0.78 & 4.40 & 6.92 & 13.95 & 0.05 & 0.36 & 0.011 & 1.21 & 0.040 & 75.95 \\
\hline DW4 & 6.79 & 96.73 & 266 & 132.7 & 6.4 & 0.75 & 5.22 & 8.22 & 16.57 & 0.06 & 0.45 & 0.006 & 0.61 & 0.020 & 89.75 \\
\hline DW5 & 6.71 & 93.82 & 258 & 128.7 & 5.9 & 0.69 & 5.06 & 7.97 & 16.07 & 0.06 & 0.47 & 0.006 & 0.61 & 0.020 & 87.78 \\
\hline DW6 & 6.74 & 94.55 & 260 & 129.7 & 6.5 & 0.76 & 5.10 & 8.04 & 16.20 & 0.06 & 0.36 & 0.011 & 1.21 & 0.040 & 87.78 \\
\hline DW7 & 6.91 & 62.55 & 172 & 85.8 & 6.3 & 0.74 & 3.38 & 5.32 & 10.71 & 0.04 & 0.40 & 0.008 & 0.91 & 0.030 & 58.19 \\
\hline DW8 & 6.93 & 64.73 & 178 & 88.8 & 5.8 & 0.68 & 3.49 & 5.50 & 11.09 & 0.04 & 0.42 & 0.008 & 0.81 & 0.027 & 60.16 \\
\hline DW9 & 6.96 & 61.09 & 168 & 83.8 & 5.9 & 0.69 & 3.30 & 5.19 & 10.46 & 0.04 & 0.36 & 0.006 & 0.61 & 0.020 & 57.21 \\
\hline
\end{tabular}

Table 3 Concentration of heavy metals in the surface water and mine pit water around the granite site in Sauna Community Kano State

\begin{tabular}{|c|c|c|c|c|c|c|c|}
\hline Sample Code & $\mathrm{Pb}(\mathrm{mg} / \mathrm{L})$ & $\mathrm{Cu}(\mathrm{mg} / \mathrm{L})$ & $\mathrm{Cr}(\mathrm{mg} / \mathrm{L})$ & $\mathrm{Zn}(\mathrm{mg} / \mathrm{L})$ & $\mathrm{Fe}(\mathrm{mg} / \mathrm{L})$ & $\mathrm{Ni}(\mathrm{mg} / \mathrm{L})$ & $\begin{array}{l}\mathrm{Cd} \\
(\mathrm{mg} / \mathrm{L})\end{array}$ \\
\hline Surface Water & & & & & & & \\
\hline DW1 & 0.068 & 0.042 & 0.050 & 0.083 & 0.327 & 0.122 & 0.022 \\
\hline DW2 & 0.068 & 0.042 & 0.050 & 0.083 & 0.327 & 0.122 & 0.022 \\
\hline DW3 & 0.070 & 0.043 & 0.051 & 0.084 & 0.333 & 0.124 & 0.023 \\
\hline DW4 & 0.083 & 0.051 & 0.060 & 0.100 & 0.395 & 0.147 & 0.027 \\
\hline
\end{tabular}




\begin{tabular}{|l|l|l|l|l|l|l|l|}
\hline DW5 & 0.080 & 0.050 & 0.059 & 0.097 & 0.383 & 0.143 & 0.026 \\
\hline DW6 & 0.081 & 0.050 & 0.059 & 0.098 & 0.386 & 0.144 & 0.026 \\
\hline
\end{tabular}

Surface water (control)

\begin{tabular}{|l|l|l|l|l|l|l|l|}
\hline DW7 & 0.053 & 0.033 & 0.039 & 0.065 & 0.256 & 0.095 & 0.017 \\
\hline DW8 & 0.055 & 0.034 & 0.040 & 0.067 & 0.265 & 0.098 & 0.018 \\
\hline DW9 & 0.052 & 0.032 & 0.038 & 0.063 & 0.250 & 0.093 & 0.017 \\
\hline
\end{tabular}

Water Quality using WQI

The impact of artisanal mining of granite on water quality of the surface water and mine pit water was evaluated using WQI. The sampling codes are as defined in Table 65. Control samples were also collected at the appropriate sections of the surface water.

The water quality of the surface water and mine pit water assessed by means of water quality index (WQI) is as presented in Table 68.

Table 68 Water quality of water systems around the granite site in Sauna community, Kano State

\begin{tabular}{|l|l|l|}
\hline S/N & Water Systems & Water Quality Index (WQI) \\
\hline 1 & Surface water (control) & 170 \\
\hline 2 & Surface water (test) & 213 \\
\hline
\end{tabular}


The surface water was polluted by cadmium, lead, nickel and chromium as the mean concentration of these four heavy metals occurred at higher concentration than the prescribed levels of WHO and SON. Consequently, the water quality ranking is very poor at WQI value of 213 (Table 68). The mine pit water is also of poor quality having been polluted by cadmium, lead and nickel yielding WQI of 178 . The control with WQI of 170 indicates that it is also polluted but by some other activities that have nothing to do with the granite mining activities. However, the granite mining activities simply exacerbated the pollution.

Research on the Fena River in Ashanti Region Ghana shows that the results obtained from the analysis of the heavy metals shows that the concentration of the different metals varied from site to site. The concentration of the metals $\mathrm{Cu}$ and $\mathrm{Zn}$ were below the WHO permissible limit within the study period in the study area. The metal concentration $\left(\mathrm{mgL}^{-1}\right)$ in water was as follows: $\mathrm{Cd}>\mathrm{Pb}>\mathrm{Fe}>\mathrm{Zn}>\mathrm{Cu}>\mathrm{Hg}$. The highest mean concentration of $\mathrm{Pb}$ measured in the river was $0.72 \mathrm{mgL}^{-1}$. The minimum and maximum values of $\mathrm{Pb}$ measured within the study area are 0 and $1.04 \mathrm{mgL}^{-1}$, respectively. (Albert Ebo Duncan; 2020).

Levels of heavy metals in water resources and the potential health risk have been studied in the mining areas of Abakaliki. This includes local communities of Enyigba, Ameka, Ameri, Amorie, Amanchara and Mkpuma Akpatakpa where mining has been ongoing for over three to five decades. Result shows the levels $\mathrm{Pb}^{2+}>\mathrm{Hg}^{2+}>\mathrm{As}^{2+}>\mathrm{Cd}^{2+}>\mathrm{Mn}^{2+}>\mathrm{Ag}^{2+}>\mathrm{Se}^{2+}>\mathrm{Ni}^{2+}>\mathrm{Cr}^{2+}>\mathrm{Cu}^{2+}$ in the area. Ameka and Mkpuma Akpatakpa mining areas recorded higher concentrations of the geochemical constituents than other communities. Acidic to slightly basic waters exists for the areas, while the abandoned mines showed considerably lower concentrations than the active mines. Water sources around active mines are polluted and hence considered unfit for many domestic and agricultural uses, especially for drinking and feeding of live stocks. (Obasi, P.N.et al; 2020)

\subsection{Concentration of the heavy metals in the surface water sediments and soil environment of the granite} site in Sauna community Kano State

The concentration of the heavy metals in the sediments and soil of the surrounding environment of the granite mine site in Sauna community Kano State is as presented in Table 4

Table 4 Concentration of heavy metals in soil and sediments around the Granite mine site in Sauna community Kano State. DS01-DS05 represent soil samples whereas DSe1-DSe8 represent stream sediments samples at granite site

\begin{tabular}{|l|l|l|l|l|l|l|l|}
\hline Sample & Ni & Fe & Pb & $\mathrm{Cu}$ & $\mathrm{Cr}$ & $\mathrm{Zn}$ & $\mathrm{Cd}$ \\
$\mathrm{ID}$ & $\mathrm{mg} / \mathrm{kg}$ & $\mathrm{mg} / \mathrm{kg}$ & $\mathrm{mg} / \mathrm{kg}$ & $\mathrm{mg} / \mathrm{kg}$ & $\mathrm{mg} / \mathrm{kg}$ & $\mathrm{mg} / \mathrm{kg}$ & $\mathrm{mg} / \mathrm{kg}$ \\
\hline Soil & \multicolumn{7}{|l|}{} \\
\hline DSO1 & $<0.01$ & 13.463 & 40.64 & $<0.01$ & $<0.01$ & 3.45 & 1.34 \\
\hline DSO2 & 5.18 & 17.753 & $<0.01$ & $<0.01$ & $<0.01$ & 5.69 & $<0.01$ \\
\hline DSO3 & $<0.01$ & 12.072 & 22.96 & $<0.01$ & 73.45 & 10.78 & $<0.01$ \\
\hline DSO4 & $<0.01$ & 13.026 & 74.09 & $<0.01$ & 17.02 & 18.56 & $<0.01$ \\
\hline DSO5 & $<0.01$ & 19.543 & 73.81 & $<0.01$ & $<0.01$ & 7.07 & 3.65 \\
\hline Sediment
\end{tabular}

\section{Pollution Assessment and Ecological Risks of the Heavy Metals in Sediments and Soil}

The contamination factor $(\mathrm{CF})$ for all the heavy metals in the sediments of the surface water were below the background levels hence indicating there was no contamination of these heavy metals in the sediments. Given 
the degree of contamination of 0.9 for the sediment which is less than 8.0 , the degree of contamination of the sediment is classified as insignificant. The pollution load index (PLI) is less than unity indicating no pollution. The geo-accumulation index (Igeo) is less than zero for each of the heavy metals indicating non-pollution. The potential ecological risk index of the heavy metals in the sediment is evaluated as 2.4 which is far less than 40 indicating low/insignificant ecological risks.

The contamination factor (CF) for cadmium is at background level in the soil with the rest of the heavy metals below the background level indicating that there is no contamination with any of the heavy metals. Given the degree of contamination of 1.8 for the soil which is far less than 8.0, the degree of contamination of the soil is classified as low. The pollution load index (PLI) is less than unity indicating no pollution. The geo-accumulation index (Igeo) is less than zero for all the heavy metals indicating non-pollution. The potential ecological risk index of the heavy metals in the soil is evaluated as 33 which is less than 80 indicating insignificant ecological risks.

Studies by Yahaya, S.M et al; (2021) indicates that The average concentrations of the heavy metals varied significantly $(p<0.001)$ and decreased in the following order $\mathrm{Fe}>\mathrm{Pb}>\mathrm{Cr}>\mathrm{Zn}>\mathrm{Cd}>\mathrm{Ni}$. Iron (Fe) has the highest average concentration compared with other metals studied. These agree with many reports indicating natural soils containing a significant amount of Fe. From the coefficient of variation of Fe (0.316), it suggests that less variability exists in the different sites, which reflects the homogenous spatial distribution of Fe in the area. These reveal that a high concentration of Fe in the soils cannot be conclusively attributed to mining alone, but other sources of Fe must be put into consideration. Besides, Fe has been reported to be the most abundant heavy metal in Nigerian soil.

According studies carried out by Sulaiman et al; (2019) The results of heavy metals concentrations in the soil samples revealed that the soil contains substantially amount of metals determined $(\mathrm{Pb}, \mathrm{Cu}, \mathrm{Cd}$, and $\mathrm{Cr})$ due to illegal mining activities taking place in the area. The Geo-accumulation index (Igeo) examined in this study revealed that the soil samples to be unpolluted to moderately pollute of all studied metals while the contamination factor $(\mathrm{Cf})$ and degrees of contamination $(\mathrm{Cd})$ of the soil as very slightly contaminated to slightly contaminate by $\mathrm{Cr}$, and $\mathrm{Cd}$. The pollution load index (PLI $>1)$, were all less than 1 for each metals in all the studied sites, thus indicating perfection and Ecological risk assessment showed low ecological risk index with values less than $\mathrm{Ri}<150$.

\section{CONCLUSION}

From the results obtained, it is clear that there is low ecological risk. There is low degree of contamination by heavy metals through artisanal or small scale mining activities in the area under study.

\section{References}

Olufemi Julius Ayodele, Olubunmi Samuel Shittu, Temitope Balogun. Heavy Metal Pollution Assessment of Granite Quarrying Operations at Ikole-Ekiti, Nigeria.International Journal of Environmental Monitoring and Analysis.Vol. 2, No. 6, 2014, pp. 333-339. doi:10.11648/j.ijema.20140206.16

E.C. Merem; International Journal of Mining Engineering and Mineral Processing 2017, 6(1): 1-19. DOI: 10.5923/j.mining.20170601.01

B.A. Adelekan et al 2011. International Journal of the Physical Sciences Vol. 6(5), pp. 1045-1058, 4 March, 2011 Available online at http://www.academicjournals.org/IJPS DOI: 10.5897/IJPS10.495 ISSN 1992 - 1950 (C2011 Academic Journals 
Tsafe A. I., 1Hassan L. G., 2Sahabi D. M., 3Alhassan Y. and 1Bala B. M. (2012)

Assessment of heavy metals and mineral compositions in some solid minerals deposit and water from a gold mining area of Northern Nigeria. International research journal of geology and mining (irjgm) (2276-6618) vol. 2(9) pp. 254-260, November 2012

Ebenebe PC, Shale K, Sedibe M, et al. South African Mine Effluents: Heavy Metal Pollution and Impact on the Ecosystem.Int J Chem Sci.2017;15(4):198 @ 2017 Trade Science Inc

Yahaya, S.M., Abubakar, F. \& Abdu, N. Ecological risk assessment of heavy metal-contaminated soils of selected villages in Zamfara State, Nigeria. SN Appl. Sci. 3, 168 (2021). https://doi.org/10.1007/s42452-021$\underline{04175-6}$

Wu Y, Yang J, Zhou X, Lei M, Gao D, Qiao P, Du G (2015) Risk assessment of heavy metal contamination in farmland soil in Du'an Autonomous County of Guangxi Zhuang autonomous region, China. Huan jing ke xue= Huanjing kexue 36(8):2964-2971

SULAIMAN, MB; SALAWU, K; BARAMBU, AU. Assessment of Concentrations and Ecological Risk of Heavy Metals at Resident and Remediated Soils of Uncontrolled Mining Site at Dareta Village, Zamfara, Nigeria. J. Appl. Sci. Environ. Manage. Vol. 23 (1) 187-193 January 2019. Article ID 2378560 । https://doi.org/10.1155/2020/2378560. Vol. 2020.

Obasi, P.N., Akudinobi, B.B. Potential health risk and levels of heavy metals in water resources of lead-zinc mining communities of Abakaliki, southeast Nigeria. Appl Water Sci 10, 184 (2020). https://doi.org/10.1007/s13201-020-01233-z 